\title{
Utazó kulturális minták és a diaszpórák letelepedése
}

\section{Travelling cultural patterns and the establishment of diasporas}

\author{
NAGY TERÉZIA
}

KULCSSZAVAK: diaszpóra, hibriditás, utazás, transznacionalizmus

\begin{abstract}
ABSZTRAKT: Tanulmányomban a diaszpórákat a transznacionális terek, kulturális minták cseréjének szempontjából interpretálom, s teszem ezt több éves terepmunka alapján. Vizsgálom az utazás, valamint az etnohomogén és transznacionális kapcsolatok hatásait a kulturális túlélésre, a beilleszkedésre és a transznacionális terek kialakulására. Írásomban az Otthontól a befogadó társadalomig és azon túlra tett utazások állomásai, a diaszpórák letelepedése és kapcsolatai, valamint a diaszpóraközi kapcsolatok jelennek meg. Úgy vélem, hogy mindezek együttesen hatnak abba az irányba, hogy a diaszpórák inkább a globális diaszpórahálóba, s nem (vagy alig) a befogadó társadalom szövetébe illeszkednek.

A Kelet- és Nyugat-Afrika, Maghreb, illetve Dél-Ázsia országaiból érkezett menekültek és diaszpóráik körében végzett terepmunka és életútinterjúk eredményének egy olvasatát tárom az Olvasó elé, amelyben a hibriditás és a diaszpóra etnospecifikus súrüsödését okozó erők közül az utazást és a transznacionális kapcsolatok pozitív (és néha negatív) hatását vizsgálom.

A hibriditás, transznacionalizmus, diaszpóra fogalmainak rövid körüljárása után kutatásom konklúzióit a diaszpórák formálódásának időbeliségét követve írom le. A diaszpórák értelmezésében nélkülözhetetlen az egzotikum és a mitikus Otthon szerepének beemelése, továbbá a migránsok, a kultúrák közötti állandó fordítás, a reflexivitás interpretálása, amelyek mind hozzájárulnak a diaszpórák kialakulásához, a transznacionális cserék lebonyolításához és végső soron a bezáródáshoz vagy épp a hibrid identitások létrejöttéhez.
\end{abstract}

\section{KEYWORDS: diasporas, hybridity, travel, transnationalism}

ABSTRACT: This study applies the viewpoint of transnational spaces and exchanges of cultural patterns to the term of diaspora, based on fieldwork in diasporas in Hungary. The effects of travel, along with ethno-homogeneous and transnational relationships on cultural survival, integration and production of transnational spaces are analysed. In the process of migration, hybrid realities come into existence by the activities of migrants, travellers, resettled people and also by the behaviour of the host society. Cultural elements and information are exchanged through transnational connections, cultural translations and observation of each other. The diasporas'

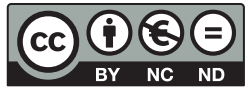


main characteristic is the reflexivity about cultural differences and this reflexivity is one of the reasons why the diasporas many times lock themselves in. However they are not hermetically isolated. Central to a diaspora is a concentrated space of cultural elements brought from home and a space for being in an essential culture; furthermore it is the place for practising religion and traditions. Nevertheless on the borders of diasporas there are places of cultural barter and spaces of transnational contacts. Some of the diasporas open up for each other and make some intercultural contacts by trading "the exotic" - for reasons of creating a livelihood and neo-integration. Global networks of diasporas and travellers are special actors generating hybridity. These are exchanging cultural elements between home and diasporas as well as among ethno-homogeneous diasporas.

The findings of this study also establish that networks of ethnically and religiously homogeneous communities are created by using the host society's institutions and spaces. We may consider these networks and communities as innovative and creative elements, and in their peripheries there are stages of cultural exchange. Hybrid identities are formed continuously in the course of travel, and their formation helps in the settling process and in building an existence. We can hardly imagine post-modern society and social spaces without intercultural entities such as what the diasporas naturally develop around themselves and which are inseparable from any interpretations of travel.

\section{Bevezetés}

Tanulmányomban a diaszpórák világát a kulturális csere, a hibriditás és az utazás tükrében vizsgálom. Megközelítésemben az utazás olyan, háttérbe szorított jellegzetességeket is magába foglal, mint a közbenső állomások hatása, az utazást motiváló narratívák, valamint a továbbutazások szerepe a hibriditásban. A valós térben megtett utazások mellett a diaszpóraközi és interkulturális kapcsolatok is szerepet kapnak interpretációmban. Így áttekintem az utazás transznacionális/interkulturális értelmezési lehetőségeit az Otthontól az állomásokon keresztül a befogadó országig, majd pedig tovább a globális diaszpórahálóban. A térben előrehaladó és visszaérkező migránsok saját és internalizált kulturális elemeket hordoznak, válogatnak és adnak tovább, miközben érkeznek és továbbállnak, de jelentős részük marad, transznacionális tereken van jelen, s maga is létrehoz ilyeneket.

Teoretikus megközelítésem többéves terepmunka eredményein nyugszik, amelyet Kelet- és Nyugat-Afrika, Maghreb, illetve Dél-Ázsia országaiból érkezett menekültek és diaszpóráik körében végeztem. Részt vettem a hétköznapokban, foglalkoztatott a kulturális találkozásokkal és konfliktusokkal színesített világ; a nemzeti, vallási és családi ünnepeken való részvételem pedig jutalma volt empatikus hozzáállásomnak, de egyben tovább növelte az értelmezéseim lehetőségeit. A terepmunka és megfigyelés, valamint a mintegy száz ${ }^{1}$ (narratív/strukturálatlan interjú) és számos beszélgetés eredményeként kirajzolódó értelmezést jelen tanulmányban a transznacionalizmus és a posztmodern utazás fogalmai köré koncentráltam. 
Tanulmányomban arra keresem a választ, hogy a valós térben való utazás, a kapcsolatok (etnohomogén és interkulturális kapcsolatok), valamint az internet milyen hatással van a kulturális túlélésre, a beilleszkedésre és a transznacionális terek kialakulására.

\section{Utazó kultúrák}

Amikor migrációról, menekültekről, diaszpórákról esik szó, egy térbeli mobilitást (Nagy 2009, 2010, Tilly 2001) és egy (szintén) térbeli megtelepedést szoktunk vizsgálni. Tehát azt, ahogy egy diffúz folyamat eredményeként némely kultúra képviselői áttelepülnek a világ másik részébe, és ott keresik megélhetésüket - de a vándorlás közbenső állomásait és a „megtelepedés” kulturálistársadalmi hozadékait korlátozott mértékben tártuk az érdeklődő olvasó, a társadalomtudományok értő olvasói elé. Pedig az antropológia által vizsgált kultúrák legtöbbje (s maguk a kutatók is) érintettek voltak - ha nem is olyan mértékben, mint a diaszpórák - az utazás és megtelepedés kihívásaiban. Számos vonatkozásban vizsgálták a migráció- és diaszpóra-fogalmakkal leírt jelenségeket: politikai, gazdasági, társadalmi, kulturális szempontok sorát vonták be az értelmezési keretbe (Bauböck, Faist 2010, Sik, Tóth 1996, 1998, 2000). Jelen tanulmányban arra keresem a választ, hogy az olyan posztmodern/posztkoloniális (Bhabha 1996) fogalom, mint a hibriditás (Buden 1996, Hannerz 1997, 1999, 2004b) és az utazás hogyan kapcsolhatók össze akkor, amikor menekültek vagy diaszpórák megtelepedéséről beszélünk. Az olyan értelmezéseknek, mint a hibrid identitás, az interkulturális (vagy épp multikulturális) kapcsolatok és színterek $^{2}$, már van hagyománya, de ezek mindig egy statikussá tett (lokalizált) jelenség kapcsán merültek fel, s a fogalmak dinamizmusa tünt el egy olyan vizsgált tárgy esetében, amelynek legfőbb attribútumai a dinamizmus, a mozgás és változás.

James Clifford (2001) egyetért James Boonnal abban, hogy egy ehhez hasonló kultúra „sokszerzős kitalálás, történelmi alakulat, amit bevezettek, politikai konstrukció, elmozduló paradoxon, folytonos fordítás, embléma, márkajelzés, a szembeálló identitások nem-konszenzuális egyeztetése és még sok minden más". Mindezek közül a kitalálás, folytonos fordítás és elmozduló paradoxon meghatározásokat emelném ki, hogy közelebbről megvilágíthassam a diaszpórák világának sajátságait. Az egyének kulturális elhelyezkedése kapcsán Clifford megjegyzi, hogy az utazást tekintve a „belső-külső kapcsolatok különböző módozatait kellene hangsúlyozni, azt, hogy az utazás vagy helyváltoztatás nagy súllyal átvonuló erőket is magában foglalhat - mint televízió, rádió, turisták, áruk, hadseregek" (Clifford 2001, 7.). Számára az utazás egyszerre jelent átmenetiséget, felületességet, turizmust, számüzöttséget és gyökértelenséget, valamint felfedezést, kutatást, átalakító hatású találkozást 
(Clifford 2001). Egyszerre sokszerzős diaszpóra-kultúra jön létre, amely magában hordozza a viszonylagosan homogén származású migránsok kultúráit, az útközben felszedegetett kulturális mintákat, azok értelmezését, fordítását, az állandóan reflektáló valóságkonstrukciókat. A diaszpóra végül nem egy kultúra színhelye lesz, hanem egy állandóan változó, interkulturális/transznacionális interakciókban gazdag, komparatív, reflexív mezö, amelynek a centrumában az Otthon mitikuma, kulturális elemei, s a meghitt, etnikailag homogén kapcsolatok állnak (Safran 1991, Wahlbeck 2002). Állandó interakcióban áll a környező kultúrával (esetünkben a magyar, az európai, az európai keresztény stb. kultúrával), az otthoni kultúrával, a diaszpórákban élők kultúrájával legyen az egy távoli, de etnikailag azonos, vagy épp egy közeli, de nem azonos kultúrájú diaszpóra (Clifford 2000). Egy olyan mező, ahová a kulturális elemek érkeznek, de a transznacionális találkozásokból úgy kerülnek ki, hogy elsődlegesen az azonos felé hajolnak, s úgy tünik, erősen különböznek a környező (és egyben a befogadó) kultúráktól, de végül az Otthoni kultúrától is különbözik a diaszpóra világa. Clifford (2007) úgy véli, hogy a diaszpóra és a bennszülött kultúrák között a kontinuitás érzékelésében rejlik a különbség - az utóbbinál a hely, a rokonság, a nyelv és a tradíciók folytonosságát láthatjuk, de a diaszpórákban fellelhető törések és kötődések (az elveszett Otthon, a részleges hazatérés, a relációs identitás, a globális kapcsolathálók) már részei a „bennszülött” tapasztalatoknak. $S$ bennszülöttként ${ }^{3}$ értelmezhetjük a befogadó kultúrát is: a cliffordi oppozíció, illetve annak feloldása érvényes. Korábbi könyvében (Clifford 1997) a diaszpórákat a nemzetállam normatív területén és időbeliségén kívül állóknak ábrázolja, egy törzsként, akiknek bonyolult a politikai és kulturális státusuk, s akiknek a legfőbb jellemzője, hogy itt élnek, de egy másik helyre emlékeznek/vágyódnak (Clifford 1997, 255. és Clifford 2000). A kontinuitás hiánya, az Otthon távolléte további két gondolatot vet fel: vajon a távollétnek (az Otthontól való eltávolodásnak) ez csupán egy állomása-e, s vajon az utazó kultúrák megállapodnak-e, vagy az utazás a diaszpóralét eleme?

Megfordítva, illetve kiszélesítve Clifford gondolatait az utazókról, akik szeretnek helyeken áthaladni, azt láthatjuk, hogy a migránsok, menekültek sokszor nem szeretnek, de áthaladnak helyeken, határokon, országokon. S szemben a klasszikus utazóképpel, nem az élmények végett látogatják meg e helyek többségét, hanem a túlélés vagy egzisztenciateremtés reményében (Bauman 1999). Az is fontos szempont - Clifford az antropológus mint utazó kapcsán írja le (2001) -, hogy a lokalizáció során kitörlődik néhány fontos határterület, amely nélkül a migránst mint utazót vagy a migrációt mint utazást nem értelmezhetjük, így azokat a kontextusokat sem, amelyek az utazást kísérik. Mint ahogy az eszközöket sem, amelyek lehetővé teszik, hogy a térben haladjanak, s azokat a helyeket sem, amelyeken keresztül eljut a migráns oda, ahol azután a társadalomtudomány diaszpóratagként értelmezheti. Nemcsak a már-már romantikus, de hátborzongató kép a vonat alján, kamionokba bezárt vagy más módon rejtegetett menekültek vagy épp legálisan utazó mig- 
ránsok képe kell, hogy megjelenjen az értelmezésben, hanem azok a transznacionális találkozások is, amelyek az Otthontól a megérkezés helyéig - nevezzük átmenetileg így - elvezetnek: az embercsempészek, a tranzitországokban megjelenő patrónusok, munkaadók, bolti eladók vagy épp humanitárius segélyszervezetek munkatársaival való találkozások. Ezek eszközei is az útnak, amennyiben pénzzel, élelemmel vagy egy-egy információval segítik a továbbjutást, vagy épp a további (távolabbi) célok kitűzését. Tágabb értelemben ilyennek tekinthetők az utazást előkészítő terveket előhívó narratívák is, amelyek arról szólnak, hogy azon a másik helyen jobb. Az utazás során számos transznacionális/kultúraközi kapcsolatot építenek ki, számos kultúrával találkoznak, ami még egy klasszikus értelemben vett utazó képzeletét is megmozgatja. Gondoljunk arra, hogy mire a legtöbb szubszaharai menekült Kelet-Európába elér, a maghrebi, közel-keleti, török, görög és balkáni területeket érinti, s ott-tartózkodása során számos tapasztalattal gazdagodik, amelyek egy része a kulturális különbségek áthidalását teszi szükségessé.

Az utazás így magában foglalja az interkulturális/transznacionális praxisokat (Hannerz 2004a és 2004b), az internalizált kulturális elemek - a származási kultúrából és a közbenső állomásokon megismert elemek - szállítását, s végül a letelepedést vagy átmeneti megállást, a marasztaló vagy továbbutazásra serkentő vágyakat és kudarcokat.

\section{Utazó kulturális minták}

Amint egy távoli kultúra képviselője - ha nem is e tisztségében, csak épp migránsként - megérkezik egy országba, számos kulturális élménnyel gazdagabban, nemcsak saját, születési kultúráját hozza magával, hanem sok internalizált kulturális elemet is. Amikor azonban letelepszik, s megkeresi az etnikailag homogén közösséget, ezen elemek háttérbe szorulnak, s csak az interkulturális praxisban való jártasságban nyilvánulnak meg.

A saját kultúra két szintéren jelenik meg - a diaszpóra otthonos melegében és a befogadó társadalom (illetve a diaszpórák világa) felé mutató kultúraközi találkozásokkor. E megkülönböztetés nem véletlen, hiszen az utazók a befogadó társadalom felé „csökkentett mértékü idegenséget” kívánnak mutatni, illetve olyan egzotikus kulturális elemeket, amelyek elfogadhatók, s vonzóvá tehetik őket ${ }^{4}$.

Az utazó kulturális minták egy része üzleti céllal kel útra: a vízipipától a perzsaszőnyegen át a djembedobokig sokféle áru érkezik, amelyek jelentős része a befogadó társadalom otthonában végzi, de ilyen áru egy-egy törzsi szokás, hagyomány vagy tánc egyszerüsített kínálata is, amelyekről a „felesleges”, azaz bonyodalmakat, értelmezési nehézségeket jelentő, szimbolikus jelentéseket eltávolítják, s fogyaszthatóvá teszik.

A diaszpórán belül azonban megnyilvánulnak azon kulturális különbségek is, amelyeket kifelé nem szívesen mutatnak, hiszen nehezen értelmezhe- 
tők például egy távoli nemzeten belüli etnikai/politikai/nyelvi különbségtételek. Így a diaszpórán belülre differenciáltan érkeznek a kulturális elemek, a hazai politikáról, gazdasági ügyekről szóló információk.

\section{Ha egy diaszpóra megtelepszik}

Az út végén egy külső meghatározás szerint befogadó társadalomhoz ér a migráns, azonban az első találkozásoktól kezdve a kapcsolati kudarcain keresztül a már ott élő migránsok narratíváiból levont következtetésekig arra ösztökélik őt, hogy megkeresse azokat, akikkel bizalmas kapcsolatot teremthet, $\mathrm{s}$ akik az egzisztenciaépítésben segíthetik. Ez a diaszpórák világában található meg számára. Azonban mindig vannak elsők - akik elsőként érkeznek, s nem találnak etnikailag/vallásilag homogén közösséget: ők a hasonlóság/különbözőség dimenziója mentén alakítanak ki kapcsolatokat, s a további migránsok érkezése után, ha már valamelyest számosabban vannak jelen a diaszpórák szférájában, leválnak, s megkezdik a saját világuk kiépítését. Nemzeti, vallási és családi ünnepek ${ }^{5}$ együtt való megülése, közös internetezés, a „hazai” hírek együttes olvasása-átbeszélése, egy-egy szabad este közös eltöltése révén lépésről lépésre közelebb kerülnek ahhoz, hogy maguk között keressék a funkcionális, baráti vagy segítő kapcsolatokat. A munka világa azonban ekkor még a diaszpórán kívül található, és viszonylag hosszú idő kell, hogy a munkából szerzett jövedelem, a hazai és más diaszpórában élő rokonok és ismerősök támogatásával egy-egy tag létre tudjon hozni valamiféle kisvállalkozást (büfé, kereskedés, piaci stand vagy mobiltelefon-üzlet, esetleg valami illegális üzlet ${ }^{6}$ formájában), amelynek fejlődése részben a diaszpóra további tagjain, részben pedig mindannyiuk kapcsolathálójának kiterjedtségén is múlik (Nagy 2007). Egyúttal azonban lehetőséget teremt további diaszpóratagok munkavállalására, s a lojalitások szimbolikus és pragmatikus megerősítésére.

A megtelepedés a befogadó társadalom testében jön létre, ahhoz sok szálon kötődik: hivatalok, adózás, lakhatás és munkavállalás során kerülnek kapcsolatba, de nyilvánvalóan a befogadó társadalom szolgáltatásait veszik igénybe az élet legtöbb területén. A fogyasztás és kereskedelem, valamint a szórakozás azok az entitások, amelyek a befogadó társadalom felől a diaszpórák világa, majd a saját diaszpóra felé húzódik a diaszpóra növekedésével párhuzamosan. A megtelepedés egyszerre történik a befogadó társadalom és a diaszpórák világa által szabott keretek között, de mind az egyes diaszpórák, mind azok tagjai egyre inkább a különbségtevések mentén - akár „elkülönbözödés"-ről is szólhatunk! - a diaszpórák felé húzódnak. A különbségtételekre szemléletes példa a fiatal szomáli diaszpóra esete.

Úgy definiálják, hogy ők nem fehérek, nem feketék, de nem arabok; országuk tagja az Arab Ligának, de az arabok mégsem tekintik egyenlőnek öket; 
muszlimok a keresztényekkel szemben, szunnik a síikkel (néha a szúfikkal) szemben... ${ }^{7}$ Ezzel egyidejüleg sokféle diaszpórával is megtalálják a hangot: muszlimokkal muszlimként, szubszaharai keresztényekkel az afrikai mivolt révén, oromo etiópokkal az etióp külpolitika-ellenességgel, közel-keletiekkel a maghrebi arabellenességgel jelzett narratívákban lelik meg a közös hangot.

A megtelepedő diaszpórákra nemcsak ezen látens határok jellemzők, hanem a narratíváikban számosan fellelhető sztereotípiák - magyarokra, európaiakra, más diaszpórákra vonatkozóan. Ezek a sztereotípiák azonban funkcióval bírnak: egyrészt segítik az öndefiníciókat, az identitást, a kultúrák közötti tájékozódást, valamint a kulturális túlélést ${ }^{8}$. A kulturális túlélés ugyanis részben abból táplálkozik, hogy ők maguk miben mások (Wahlbeck 2002). Emellett közösségi szinten megfigyelhető a kíváncsiság, rácsodálkozás és a (számukra) Mások megértésére való törekvés, amely éppen a közösségi szinten terjedő és diaszpóraközi sztereotípiák hatására a félreértésnek is teret enged. Ugyanakkor ez a fajta érdeklődés teszi lehetővé a kozmopolita (más szempontból: multiplex) kötődéseket, s a kölcsönös kíváncsiság hozza létre azokat a transznacionális kapcsolatokat, ahol a kultúrák világa találkozhat (például fesztiválok, klubok, éttermek terein).

A primer kötődések (A. Gergely 2005) és az identitás a diaszpórához és a mitikus Otthonhoz kötik a migránsokat (Clifford 2000), ugyanakkor sok esetben az akkulturáció (Hannerz 1997, Phillimore 2011), a közösségteremtésre való készség, a hajlékonyság is megjelenik. A diaszpórákat sem tekinthetjük azonban homogénnek. A származás (etnikai, klánbeli hovatartozás), a politikai meggyőződés, a tradicionálisabb vagy modernebb életforma, a vallásosság mértéke szerint a diaszpórák belülről fragmentáltak (Olomoofe 2000). Wilson (2009) centripetálisnak tekinti a diaszpórát, s úgy vélem, hogy egyetérthetünk vele, ha arra gondolunk, hogy a diaszpórák közepén egyfajta kulturális elkötelezettségben, lojalitásban mérheto” „sűrüsödés” található, míg a diaszpórák peremén inkább megfigyelhetők a transznacionális kapcsolatok. A diaszpóra belsejében olyan aktorok vannak jelen, akik számára megélhetést és/vagy biztonságot az otthonos közeg biztosít: idetartoznak azok, akiknek a megélhetése, vállalkozása diaszpóraspecifikus, de itt találhatók azok is, akik egzisztenciális és kapcsolati kudarcok után a diaszpóra ismerős világába zárkóznak. A diaszpóra peremén azonban az interkulturális kapcsolatok, a performance-szerű kultúraismertetések és a befogadás óhaja állnak (ld. az Izgalmas dolgok a diaszpóra peremén c. alfejezetet), miközben a vallásosság és a saját kultúra felől nyitottan tekintenek a többi kultúra felé. Azonban a kapcsolati kudarcok és a kulturális távolságok/konfliktusok a diaszpóra belseje felé vezetik a korábban esetleg nyitott, transznacionális kapcsolatokat építő, integrációra vágyó aktort (Nagy 2007, 2009, 2010). A visszavezető út nemcsak a kapcsolatokban figyelhető meg, hanem például egy (legalább átmeneti) vallásosabb életszakasz bekövetkeztében is. A kapcsolati kudarcokat követő neointegráció ${ }^{9}$ egyik sajátsága a rigorózus(abb) következetességgel alkalmazott (saját) kulturális válaszok jelenléte. 
A diaszpóra megtelepedését azonban az elutasítás (kirekesztés és elhatárolódás) mellett a türelem és kezdeményezőkészség jellemzi, valamint az innovatív megoldások a megtelepedésre, a sokaknál fejlett (másoknál kudarcokkal terhelt és így visszafogottabb) kapcsolatépítő készség, amennyire a kulturális és vallási szabályok engedik. További vizsgálatra érdemes az a közösségépítő mechanizmus, amely a túlélést (kulturális és egzisztenciális túlélést) segíti, s amely a hasonlóságok és különbségek felkutatása mellett feltárja a csoport erőforrásait és készségeit.

\section{Érkezök}

A diaszpórába három irányból érkeznek új tagok: a távoli hazából, az európai diaszpórákból, valamint az Otthon és a befogadó ország közötti terület diaszpóráiból. Az utóbbi esetben egy korábbi neointegráción átesett, a megtelepedés rutinjával, de valamelyest mindig útra készen álló (Bauman 1999) új tagok próbálnak beilleszkedni. Az ő helyzetük a legegyszerủbb: tapasztalatokkal rendelkeznek arról, hogy milyen a diaszpóra-lét, transznacionális tapasztalataik a mindennapi életben segítik őket, miközben megszokták, hogy a hazájuktól távol, idegen közegben, idegen kultúrában alkotott szigeten éljenek (Derrida 2004, Simmel 2004, Waldenfels 2004). Korábbi tapasztalataik abban is segítenek, hogy egy új adaptációs kényszerhelyzetben (A. Gergely 2005) hogyan alakítsák ki identitásukat - a diaszpórában.

„Majdnem két évet éltem Isztambulban, persze illegálisan, de nem tudtam továbblépni, meg arra gondoltam, hogy amíg megvan a megélhetésem, $s$ tudok haza is küldeni, addig minek próbálkozzam [a továbbjutással]. Az öcsém is jött, a nagynénénk maradt a húgommal, tudtam nekik pénzt küldeni. Persze a családból sokan már Londonban vannak régóta, oda akartam eljutni, de nem ment. (...) Amikor ideérkeztem, na, nem ide akartam, de... szóval nem volt nehéz, rögtön mentem Budapestre, ott a nagy pályaudvaron találtam egy arabot, az megmondta, hol találok pakisztániakat, $s$ onnan ment minden... kaptam munkát, feketén persze, de tudok hazaküldeni néha pénzt. Gyakran összejövünk, de hát végül is pakisztániakkal meg indiaiakkal dolgozom" (Said, pakisztáni férfi).

Valamivel nehezebben találják meg a számításukat azok, akik csak éppen átszálltak vagy rövid időt töltöttek egy-egy „állomáson” a hazájuktól Magyarországig. Az újrakezdésben sincs jártasságuk, a kapcsolatépítésük is csak egyegy funkcióra irányul, s csak később kezdik el ápolni is a felvett kapcsolatokat. Ugyanakkor hamar megtalálják az etnikai/vallási/nyelvi homogén csoportokat, szerencsés esetben a diaszpórájukat, amelyben a kapcsolatokon keresztül a neointegráció kiépül, s a felmerülő problémák is megoldhatókká válnak.

A nyugati diaszpórákból visszaérkezők ugyan rendelkeznek a megtelepedés rutinjával, számosan megőrzik a korábbi, helyi kapcsolataikat, s így rög- 
tön megvan a helyük a diaszpórán belül, ugyanakkor kudarcként élik meg, hogy visszajönni kényszerültek - akár azért, mert a hatóságok kényszerítik őket, akár azért, mert nem sikerült legitimálniuk ottlétüket, s az egzisztenciájuk bizonytalansága miatt inkább a visszatérést választották. A kudarc érzete mellett sokszor az új útra, új lehetőségekre vonatkozó információk begyűjtése emészti fel energiájukat (és pénzüket), így a kudarcok sorozatossá válnak. „Itt vagyok, de hol azt nézem, hogy otthon mi van, hol meg azt nézem, hogyan juthatnék vissza Angliába, néha azt se veszem észre, hogy itt mi történik..." (Indho, szomáli férfi).

\section{Izgalmas dolgok a diaszpóra peremén}

A diaszpóra imaginárius peremén lelhető fel a reflexív kultúramegközelítés pragmatikus oldala: az európai-afrikai, európai (benne: magyar) és muszlim intertextusok (másképpen tekintve: hibrid identitások), mindez a transznacionális, interkulturális kapcsolatok, a kultúra- és vallásközi kommunikáció tereinek tekinthető (Clifford 2000). Az érdeklődés és némely gyakorlatiasabb dolog (hétköznapi találkozások, hivatalok, munka és szórakozás) a diaszpórán kívülre, a sokrétű kötődések többsége azonban a diaszpóra felé kötik az aktorokat, miközben a kultúra megőrzése és az asszimiláció (A. Gergely 2005, Clifford 2000, Geertz 2001) fogalmait kell használnunk. A családi/közösségi autoritások elvesztése, illetve megkérdőjeleződése, a mainstream kultúra hatása, az elfogadásra való törekvés együttesen eredményezik azt, hogy az aktorok - még ha tradicionális, vallásos közegből érkeztek is - éjszakai szórakozóhelyeken, sportközvetítéseken, kocsmákban, konditermekben töltik a szabadidejüket. Igaz, ez csak egyetlen eleme az asszimilációra való törekvésnek, ahogy az öltözködés, testdíszítés (smink a nőknél, frizura mindkét nemnél, (nem törzsi) tetoválás stb.), fogyasztás területein is sok példát találhatunk. Azonban számosan az asszimilációs törekvések után az etnikai/vallási közegbe húzódnak vissza. A frissen érkezettek esetében az asszimilációs és neointegrációs törekvések ráadásul egyidejüek a „hazai hírek” intenzív fogyasztásával, ami büszkeséggel és aggódással tölti el őket. Egyszerre kötődnek a nációjukhoz, etnikumukhoz, valamint válnak anti-nacionalistává (A. Gergely 2005). Elfogadó lépések mellett ők maguk is igényt nyújtanak be arra, hogy ne a látható és feltételezett etnikai/vallási tulajdonságaik alapján ítéljék meg őket. Ugyanakkor - ahogy fentebb is írtam - az egyszerüsítés okán ők is etnikai-vallási kategóriákban gondolkodnak, s miközben viszonylag homogén szigeteket hoznak létre, a diaszpóra határain túlra is tapogatóznak. Hibrid identitások jönnek létre, amelyeket a diaszpóra-identitás, az Otthon reflexiói, a befogadó társadalommal való csereberék és kudarcok hoznak létre.

A diaszpórák peremén, a kulturális események idején (például menekültek napja, Afrika-nap, fesztiválok, nemzeti ünnepek) az egzotikum megmuta- 
tása is cél (Nagy 2008). A performance tárgya azonban a kulturális megismerés és sztereotipizálás mezsgyéjén történik: feltételezik a befogadó közeg számára elfogadhatónak minősülő motívumokat (rítus, tánc, étel stb.), s ezeket kínálják fel az egzotikumra éhes publikumnak. Így az európai/magyar szem számára elfogadható, de „hamis” egzotikum valósul meg, s ez az entitás nem segíti a beilleszkedést, hiszen az Egzotikus éppen növeli a távolságot.

Ugyancsak a diaszpórák peremén jönnek létre a kapcsolatok született muszlimok és magyar megtérők, afrikai keresztények és magyar keresztények között vagy épp nyugat-afrikai szúfi muszlim raszták és magyar raszták között, s ezeken a perifériákon nyílik meg a lehetőség a másik kultúrájának valóságosabb megismerésére. De ezek a kapcsolatok intenzívebbek és intimebbek is, mint más véletlenszerü kapcsolatok, s alapját képezhetik a neointegrációnak, a kapcsolatokon keresztül az egzisztenciális igények kielégítésének.

A migráns-magyar házasságból született, illetve a migráns házasságból született gyermekek helyzete is itt volna értelmezhető a többszörös kötődések okán, de inkább egy külön tanulmányt, a két (esetleg több) kultúra közöttiségre, a nyelvhasználatra fókuszáló kutatást érdemel.

\section{Cserebere kulturális elemek}

A kultúra esszenciái, illetve egyes elemei kerülnek forgalomba a diaszpóra részéről, s a cél: a Másik megigézése és figyelmének lekötése - a sikeres neointegrációért, a megtelepedő (és az egzotikumra épített) vállalkozásért. A transznacionális cserére felajánlott kulturális javak az „elfogadható egzotikum" (Nagy 2008) mezejére utalnak (arab ételek, afrikai táncok, vízipipa, perzsa szőnyegek, indiai füstölők stb.) és a befogadó társadalom tagjának kozmopolitizmusát is elismerik egyúttal. A csere másik oldalán olyan absztrakciókat vélelmezhetünk, mint az elismerés, elfogadás, befogadás, valamint a gazdasági és kapcsolati tőke. Ugyanakkor a cserének nem tárgyai a vallási, politikai nézetek, a kereskedelmi praxisok, s csak korlátozott mértékben az egészségre irányuló tudások, de kölcsönös figyelemre méltó az életforma. (Az életformáról ld. még Hannerz 1999, a kulturális egymásrahatásról pedig Hannerz 2004b.)

A befogadó társadalom felől a popzene, rap és reggae, a hollywoodi film, valamint a konyhamüvészet egy-egy eleme áramlik (amellett, hogy a nyelvelsajátítás bizonyos mértékű kulturális áramlást is feltételez). A fúziós konyha diaszpóra-változata például ötvözi a magyar pörkölt és az etióp wot, a magyar palacsinta és az etióp injera vagy szomáli canjeera elkészítési módjait, vagy épp a kínai tojásos rizs kerül szubszaharaiak asztalára... 


\section{A kulturális elemek cseréjének helyszínei}

A fentieket elolvasva már plasztikusan kirajzolódik, hogy a diaszpóra egyrészt nem magányos sziget, de sok szempontból távolságot tart a környező kultúrákkal. Mégis, vannak olyan helyszínek, ahol a befogadó társadalom és a diaszpóra, illetve a diaszpórák találkoznak. Egy részük olyan közösségi tér, köztér, amelyet a migránsok is használnak: a munkahelytől a közösségi közlekedés terein át a fesztiválokig számos ilyen van. Másokat részben kisajátítanak: egyegy forgalmas téren rendszeresen összegyűlnek, a legközelebbi vendéglátóegységekbe betérnek, s ha elég jelentékeny számban és rendszeresen használják ezeket, otthonosan mozognak (ilyen például a Blaha Lujza tér Budapesten). De vannak olyan helyek is, amelyek általuk jönnek létre (arab boltok, arab és török éttermek/büfék), amelyek többsége kettős használatú: a megjelenés tere/az egzotikum árusításának tere, illetve a diaszpóra tagjainak gyülekezőhelye (és néha a közös ima helye). (Mindehhez ld. Bridge, Watson 2001 és Calderia 1999, valamint Sassen 1999 gondolatait.)

\section{Utazó diaszpóratagok}

Az Otthonról Magyarországra érkező migránsok (menekültek, üzletemberek, egyetemi hallgatók) a letelepedés után további utakat tesznek meg. Sokan a menekültek közül csak tranzitállomásnak tekintik Magyarországot, ahol szerencsétlenségükre rögzítették az adataikat (beleértve az ujjlenyomatot is), de amely a továbbutazás kiindulópontja, ahogy voltak már korábbi ilyen helyek is (Nairobitól Damaszkuszig, Isztambultól Belgrádig, Karachitól Athénig vagy épp Yaoundétól Agadirig). Így sérül a neointegráció iránti elkötelezettség, és a kapcsolatépítéstől a jövedelemfelhasználásig sok minden a továbbutazás elősegítésére irányul. A kapcsolatépítés ilyenkor a távolabbi diaszpórák felé mutat, s arra irányul, hogy elősegítse az ottani egzisztenciaépítést. A kapcsolatépítésben segít az, hogy a budapesti diaszpórából korábban elvándoroltak tartják a kapcsolatot, illetve a személyes ismerősök közül korábban továbbállók segítik a hátramaradókat. Vagy, ahogy az európai szomáli diaszpórákban megfigyelhető: a kapcsolathálók átfedései az utazó aktorok kapcsolatainak is köszönhetők, illetve annak, hogy sokan még a kibocsátó- és tranzitországok állomásain ismerték meg egymást, s a kapcsolataikat megőrizték, csak a helyszín változott (Tilly 2001). Az ilyen kapcsolatok kölcsönözhetők, és a közösségi lojalitást erősítik.

A menekültek is, de méginkább más migránsok olyan külföldi utakat is megtesznek, amelyeknek nem célja az áttelepülés: családtagokat és barátokat látogatnak meg, üzleti (transznacionális és diaszpóraközi) kapcsolatokat építenek, „világot látnak” és hazalátogatnak ${ }^{10}$. Mozgékonyságuknál fogva a transz- 
nacionális és kultúrahomogén attitűdök, életformák közvetítői leginkább ők, de történeteik egyben mozgatórugói is a továbbvándorlásnak azok körében, akiknek az egzisztenciája még nem épült ki, akiknek a lojalitása esetleges ${ }^{11}, \mathrm{~s}$ akiknek erősebben reflexív a viszonyulása a lokális diaszpóra-viszonyokhoz.

Az utazások többsége egyéni, vagy legfeljebb egy autónyi együtt utazót jelent. De vannak időszakok, amikor egy-egy diaszpóráról klikkek olvadnak le, és jelennek meg más, nyugati diaszpórákban. Ennek oka a következő sajátságokban keresendő: egyrészt nem sikerül a megélhetéshez és otthonérzethez megfelelő helyzetet teremteni, másrészt a globális diaszpórahálóban (Nagy 2007, Tilly 2001) vándorlók információi is továbblépésre késztetik őket - ugyanakkor találnak egy olyan kapcsolatot, amely segíti a továbblépést. Miután egynéhányan áttelepülnek, a hátramaradókat kezdik el segíteni, majd azok a továbbiakat, egészen a klikktagok ego-hálójának határáig. Ez a segítség elsősorban információkat, alkalmi szállást és - szerencsés esetben - munkalehetőséget jelent. Így van ez a pakisztáni, közel-keleti, török, maghrebi, szomáli és kameruni közösségek körében, de a mali, szenegáli és elefántcsontpartiak az ilyenfajta összetartást - $\mathrm{s}$ általában az összetartást - hiányolják ${ }^{12}$.

A nyugatról Magyarországra érkezők között nemcsak azok vannak, akik látogatásukról érkeznek vissza, vagy épp itt tesznek egy látogatást, hanem sokszor olyan aktorok is, akik a kinnmaradást tervezték: vagy hivatalos úton küldik vissza őket, vagy kudarcok sorozata után adják fel az illegális tartózkodást.

A globális diaszpórahálóban vándorlók legalább olyan fontos aktorai az információkereskedelemnek és a kulturális elemek szállításának, mint a világháló. Az információk pillanatnyi megélhetésre való cseréje kevesek számára elérhető - egy vacsorameghívás, alkalmi szállás formájában többeknek, de az ummán (muszlim közösségen) belüli hittérítők megélhetése formájában keveseknek. Ennek ellenére - ahogy a társas élet, a pletyka bármely kultúrában az információkkal való kereskedelem kontextuális jelentősége kiemelkedően fontos. A megélhetésért küzdő menekültek körében a szabad munkavállalásról, nagyobb szociális segélyről, olcsó lakhatásról, jelentősebb bérekről, toleráns munkaadókról és diaszpórán belüli megélhetésről (és az általában vett életről) szóló narratívák olyanok, mint a szomjazóknak a kút ${ }^{13}$, ami sajnos a valóságban néha csak egy elapadó forrás.

\section{Valós és virtuális térben utazó kulturális elemek}

A migránsok/menekültek térbeli mobilitása nemcsak otthonról a diaszpóra felé áramoltatja az információkat, a kulturális elemeket (szokásokat, ízléseket, s összességében valamiféle Egzotikumot), hanem az Úton közbeeső állomások felől is. Megérkezésük után azonban nemcsak ezen kulturális elemeket és mintákat kínálják fel cserére, hanem a későbbiekben a kommunikációs esz- 
közökön keresztül áramoltatható kulturális javak elsődleges befogadói és továbbadói lesznek. Mind a befogadó társadalom nyitott tagjai felé, mind a diaszpórák körében, mind a saját diaszpórán belül (s ez utóbbi a legfontosabb) az egyéni ízlés és válogatás után felkínálják az új kulturális javakat. Az otthon és a diaszpóra közötti áramlásban a szokott módok (levél, csomag) mellett az ismerősök hálóján keresztül is érkeznek fogyasztási javak, amelyek egy része áruként jelenik majd meg. Így a pakisztáni, indiai, szomáli vagy épp kurd ismerősök globális hálóját felhasználva egyfajta futárszolgáltatás jön létre.

Egy példa az ismerősi hálókon keresztül utazó tárgyakra. Abdullahinak ${ }^{14}$ szüksége van az iskolai papírjaira, de méginkább a jogosítványára. Nővére Mogadishuból elküldi az unokabátyjukkal Nairobi Eastleigh negyedébe, ahol az elviszi Nurhoz, aki továbbadja sheik Maxamednek, akihez épp érkezik a rokona Hollandiából, s magával viszi Hollandiába a papírokat s a mások által óhajtott dolgokat (ruhanemüt, könyveket és füszereket például). Ott átadja Labaannak, aki Magyarországra érve átadja azokat Abdullahinak. Ehhez azonban szüksége volt arra, hogy Mogadishu és Nairobi, valamint Nairobi és Hollandia, továbbá Hollandia és Magyarország között utazókat feltérképezzen. Ehhez az e-mail, telefon mellett a Messenger és Facebook állt rendelkezésére, továbbá az, hogy az ismerősi hálók olyan bizalmas kapcsolatokon keresztül összeérjenek, akikre rá lehetett bízni ilyen fontos iratokat.

Az ismerős ismerőseinek hálójában való áramláshoz alapvető a bizalom, amelyet a hasonlósági szabály mentén alakítanak ki, s amely a reciprocitás elvén nyugszik.

Ulf Hannerz (1999) úgy véli, hogy a migránsok mobilitásuk révén kiveszik a részüket a kulturális javak áramoltatásából. A globalizálódó világban a transznacionális áramoltatásban az utazók mellett az informatikának és médiának is nagy szerepe van. A fájlmegosztó oldalaktól a Facebookig, a youtube-tól a hazai hírforrásokig számos olyan lehetőség van, amelyen keresztül az Otthon világából meríthet a migráns. Azonban a lehetőségek az életstílus és miliő, valamint a származás függvényében kerülnek leválogatásra. Így a vallásosabb és kevésbé vallásos, a diaszpóra centrumában élő vagy épp kozmopolita aktorok mást és mást válogatnak le.

A világhálón terjedő kulturális elemek és minták egy része az Otthon felől, míg mások a távolabbi diaszpórák felől érkeznek. A kultúra változása viszonylag gyorsan elér a diaszpórákhoz is, s a diaszpórák felől olyan változatok is érkeznek, amelyek már keresztülmentek egy transznacionális cserén. Egy részüket a diaszpórán belül terjesztik - az információk intimitása és értelmezhetősége miatt -, míg mások a diaszpóra pereméről ki is juthatnak. Az előbbire példák az anyanyelvű hírek és zenék, a vallást érintő kérdések, míg az utóbbira a nyelvismerettől függetlenül is értelmezhető zenék (djembe és darbuka) vagy táncelemek.

Az azonos származási országból érkezett, de a világ különböző részein élő diaszpórák közötti kapcsolat sokrétű: vannak ismerősi/rokoni hálók, az ismerősök ismerőseinek hálói, valamint egy-egy érdeklődési körhöz tartozók 
online közössége. A diaszpóraközi információáramlás legfontosabb témája a diaszpórákban élők helyzete, valamint az otthon történő változások. Mindezeket ismételten csak a „bizalom” mentén lehet értelmezni, hiszen rengeteg narratíva kering, amelyeknek csak egy töredéke igaz, de segíti a migránst útjának megtervezésében. A diaszpóraközi kulturális javak áramlása a diaszpórán belüli fragmentációk mentén töredezett, s jelentős szerepet játszik benne az internethasználat (Alinejad 2011), például egymás figyelmébe ajánlják egy tradicionális/jelenkori zenei, tánc-, politikai esemény vagy történelmi film linkjét. A hazai és diaszpórabeli kultúrának éppúgy vannak dívái, celebjei, hiteles vagy híres emberei, mint a befogadó társadalomnak, s az általuk közvetített értékek, gondolatok a diaszpórabeli és diaszpóraközi kommunikáció részét képezik.

Az egy helyen élő diaszpórák közötti kultúra- és információáramlást tekintve a kevésbé lokalizált kulturális elemek (dallamok és ízek, valamint a közös nyelven hozzáférhető vallási tanítások) és a nagyon is helyi sajátságokra vonatkozó információk (az őket érintő törvények változása, munkalehetőségek, új közösségi terek, befogadói és segítői kapcsolatok) áramlása figyelhető meg.

A diskurzusok minden irányban a nyugati diaszpórák szerencsésebb helyzete, a keleti/déli diaszpórák szerencsétlenebb helyzete, valamint a sikeres és sikertelen (olykor halállal végződő) utazások, megélt kihívások narratíváit is tartalmazzák. E narratívák a megtelepedés és továbbutazás közötti döntéseket nagyban segítik.

\section{Az Otthon helye a diaszpóra számára}

Az Otthon a migránsok többsége számára mindig is a szülőföldön marad, még akkor is, ha közben (máshol) letelepszik és családot alapít. A diaszpórák természetes attitüdje, hogy ápolják a szülőföld emlékét, mítoszát, a visszatérés reményét, s elkötelezettek a szülőföld iránt (Safran 1991). A beilleszkedés és szegregálódás határmezsgyéjén állva az önazonosság-tudatukat, legitimitásukat mitizált történelmi eseményekből, helyszínekből és kultúrából merítik (Safran 1991, 83-84. és Clifford 2001). Olyan narratívákat ismerhetünk meg, amelyekben az etiópok Sába királynő leszármazottai, a szomálik az amerikai had visszaverői, az afgánok az örök harcosai a vátán (haza) szabadságának...

A mitikus Otthon esszenciális leképeződése a cél akkor, amikor a diaszpóra elkezd kiépülni (Wiles 2008), de sok akadályozó tényező van: a klímától a környező kultúráig, a szakadozott családi hálózatoktól a gazdasági erőtlenségig sorolhatnánk. Bizonyos értelemben azonban a leképeződés - a diaszpórán belül vagy annak határait átjárva - sikerül: megteremtik a hierarchiát, amelyen belül a gazdasági, tudás- és vallási elit mögött felsorakoznak. A diaszpóra egyértelműen kirajzolódik, ha a kultúrát és identitást tekintjük. Ennek men- 
tén nyilvánul meg a városban: transznacionális városi terek, fragmentált, de egymáshoz közelítő diaszpóramezők jönnek létre, Budapesten kevésbé összefüggően, mint máshol, de a városlakók számára érzékelhető módon.

A migránsok, menekültek számára az Otthon távoli, a pillanatnyi élet helyszíne pedig átmeneti, ahol azonban meg kell teremteni az otthonosság érzetét, $\mathrm{s}$ ez a tevékenység egyúttal olyan állandó vagy átmeneti tereket hoz létre, amelyeket a diaszpóra birtokol (némelykor csak bitorol).

A háborús menekültek, a hontalanok számára azonban Magyarország ennél egy kissé többet is jelent: nemcsak a diaszpórán belül találják meg az otthont, de a befogadásért hálás szívvel fordulnak a társadalom felé ${ }^{15}$, még akkor is, ha nem teljes mértékben vannak pozitív tapasztalataik.

Együttesen létrehoznak olyan helyeket és pillanatokat, amelyek megidézik az otthont, ahol felidézhetők az otthon sajátságai, de amelyek egyúttal olyan szemantikai mezőben vannak, hogy magukba foglalják a befogadó társadalom világát, az Itthont, az elkülönböződést, az egzotikum performanceszerủ interpretációit és az in-group együttlétek intimitását. A kontextus - az európai/magyar kultúra és tér - lehetőségeket és gátakat rejt számukra, amelyekben biztos pont a diaszpóra mezeje, a valós és a mitikus Otthonnal fenntartott kapcsolat.

\section{Összegzés}

A migráció során, a diaszpórák megtelepedésekor hibrid valóságok jönnek létre, azaz olyan hibriditás, amelyen sokan dolgoznak: migránsok és befogadók, diaszpóraközi vándorok és áttelepülők, valamint az internetet böngésző diaszpóratagok.

A diaszpórák világában, a transznacionális együttműködés során, az információk és kulturális elemek kicserélődése következik be, ami egyszerre hatása is és mozgatórugója is a vándorlásnak. A folyamatos dinamizmus az utazás mellett a változékonyságot jelenti - a kulturális elemek cseréje, az egzotikum áruként való kínálata, az interkulturális kapcsolatok formájában. Az állandóságot a saját kultúra, vallás, nyelv mellett az Otthon felé való elkötelezettség és a reflexív ismeretszerzés jelenti. A diaszpóra a folyamatos fordítás színtere is, $s$ itt a reflexív magatartás szinte állandó a transznacionális gyakorlatban. Ez a reflexivitás eredményezi azt is, hogy az egzotikum kapcsolatokra és anyagi javakra is átkonvertálhatóvá válik, így a diaszpóráknak és tagjaiknak a befogadó társadalomban és a térben való elhelyezkedését segíti. A befogadó társadalom intézményeit és tereit használva létrehozzák az etnikai és vallási homogén közösségek hálóit, s ezeket innovatív és kreatív közegnek, perifériáit a kulturális csere színhelyének tekinthetjük. 
A diaszpórák felé tartó utazások során folyamatosan épülnek fel a hibrid identitások, amelyek a megtelepedést is, de az egzisztenciaépítést is segítik. A posztmodern társadalmat, társas tereket nehezen képzelhetjük el olyanfajta interkulturális entitások nélkül, amelyeket - láttuk - a diaszpórák természetszerủen alakítanak ki maguk körül, s amelyek elválaszthatatlanok az utazás értelmezéseitől.

\section{Jegyzetek}

1 Interjúalanyaim anonimitását névcserével oldottam meg, de a nevek tükrözik az alany nemét, etnikai és vallási hovatartozását.

2 Nem hivatkozhatunk kellő mértékben Hannerz és Bauman munkáira, de mindenképpen szükséges egy kitekintés a későmodern/posztmodern városképről, térátalakulásról, társadalomról (és annak kívülállóiról), valamint a (multi)kulturális megközelítésekről szóló, tematikáikat különbözőképp ötvöző írásokra.

3 A bennszülött fogalom klasszikus értelmét körüljáró vitában (Discussion 2006 és Barnard 2006, 1-16.) szofisztikáltan leírt jellemzők bizonyos értelemben az itt befogadó társadalomnak aposztrofált kultúrára is érvényesek, s a posztmodern kultúratudományokban elfogadott nézet a helyiek bennszülöttként való vizsgálata.

$4 \quad$ Interjú az Ali nevű középkorú maghrebi férfival.

5 Pakisztáni Basant (tavasz) ünnep, az etióp újév (enkwtatash), a muszlim eid ul-fitr stb.

6 Így pl. a pénzváltástól a drogkereskedelemig, amely később egy legális vállalkozás alaptőkéjét hozhatja.

7 Interjú Maxamed, Mohamed, Labaan, Abdi Hafiz, Abdiwali szomáli férfiakkal és Ubax szomáli nővel.

8 A kulturális túlélésről szólva Geertz $(2001,377)$ megemlíti, hogy a kultúráknak áthatolhatatlannak kell maradniuk.

9 A neointegráció a szocializáló közeg integrációjának elvesztése után hosszabb-rövidebb idővel alakulhat ki, új társas kapcsolatokon keresztül, s egyes sajátságaiban eltér az integrációtól: a kialakuló új lojalitás reflexív viszonyban áll a korábbi kudarccal, a normatív kontroll elfogadása nem természetes, hanem reflektált és megkérdőjelezett.

10 A hazalátogatás a menekültek körében sem ismeretlen, habár a hazaút az ő esetükben, ha igazolódna, a menekültstátus elvesztésével járna. De ahogy mondják: pénzzel minden megoldható, így az is, hogy az utazási igazolványba hazai pecsét ne kerüljön.

11 A transznacionális lojalitásról ld. Leichtman 2010.

12 Interjúk. Babatoura, Cisse, Ajebor, Emanuel és Zara.

13 Omar és Abdullahi szomáli férfiakkal készült interjú.

14 Interjú Abdullahival és online interjú Labaannal, szomáli férfiakkal.

15 Nem ritkán a befogadás idején aktuális kormány és miniszterelnök felé is.

\section{Irodalom}

A. Gergely A. (2005): Szórvány, diaszpóra és határfenntartás. Adalékok a szórványtipológia és a kulturális sziget kérdésköréhez. In: Ilyés Z. (szerk.): Tanulmányok a szórványról. Gondolat Kiadó - MTA Etnikai-nemzeti Kisebbségkutató Intézet, Budapest, 11-20. www.mtaki.hu/kiadványok, http://www.publikon.com/application/essay/402_1.pdf 
Alinejad, D. (2011): Mapping homelands through virtual spaces: transnational embodiment and Iranian diaspora bloggers. Global Networks, 1., 43-62.

Barnard, A. (2006): Kalahari revisionism, Vienna and the 'indigenous peoples' debate. Social Anthropology, 1., 1-16.

Bauböck, R., Faist, Th. (eds.) (2010): Diaspora and Transnationalism. Concepts, Theories and Methods. Amsterdam University Press, Amsterdam

Bhabha, H. K. (1996): A posztkoloniális és a posztmodern. A társadalmi hatóerő kérdése. Helikon, 4., 484-509.

Bridge, G., Watson, S. (2001): Retext(ur)ing the city. City, 3., 350-362.

Buden, B. (2004): Kultúrák közti fordítás (hibriditás). Magyar Lettre Internationale, 51., http://www.c3.hu/scripta/

Caldeira, T. P. R. (1999): Fortified Enclaves: The New Urban Segregation. In: Low, S. M. (ed.): Theorizing the City. The New Urban Anthropology Reader. Rutgers University Press, New BrunswickNew Jersey-London

Clifford, J. (1997): Routes: travel and translation in the late twentieth century. Harvard University Press, Cambridge

Clifford, J. (2000): Diaszpóra. Magyar Lettre Internationale, 39., 12-17. http://www.c3.hu/scripta/lettre/web/index.htm

Clifford, J. (2001): Utazó kultúrák. Magyar Lettre Internationale, 41., http://epa.oszk.hu/00000/ 00012/00025/clifford.htm

Clifford, J. (2007): Varieties of Indigenous Experience: Diasporas, Homelands, Sovereignties. In: Cadena, M. de la, Starn, O. (eds.): Indigenous experience today. Wenner-Gren Foundation for Anthropological Research. Berg Publishers, Oxford, 197-224.

Discussion (2006): Social Anthropology, 1., 17-32.

Derrida, J. (2004): Az idegen kérdése: az idegentől jött. In: Biczó G. (szerk.): Az Idegen. Variációk Simmeltól Derridáig. Csokonai Kiadó, Debrecen, 11-29.

Geertz, C. (2001): A sokféleség édes haszna. In: Geertz, C.: Az értelmezés hatalma. Antropológiai írások. Osiris Kiadó, Budapest, 374-396.

Hannerz, U. (1997): Fluxos, fronteiras, híbridos: palavras-chave da antropologia transnacional. Mana (Rio de Janeiro), 1., 7-39. Angolul: Flows, Boundaries and Hybrids: Keywords in Transnational Anthropology. http://www.transcomm.ox.ac.uk/working\%20papers/hannerz.pdf

Hannerz, U. (1999): A világvárosok szerepe a kultúrában. Replika, 38., http://www.c3.hu/scripta/replika/38/06hanner.htm

Hannerz, U. (2004a): A kozmopoliták és helyiek a világkultúrában. In: Biczó G. (szerk.): Az Idegen. Variációk Simmeltól Derridáig. Csokonai Kiadó, Debrecen, 178-191.

Hannerz, U. (2004b): Gondolatok a globális világról. In: N. Kovács T. (szerk.): A fordítás mint kulturális praxis. Jelenkor, Pécs, 73-93.

Leichtman, M. A. (2010): Migration, War, and the Making of a Transnational Lebanese Shi' $i$ Community in Senegal. International Journal of Middle East Study, 42., 269-290.

Nagy T. (2007): Migráns hálózatok, menekültek és a Határok. In: Timár J. (szerk.): Határkonstrukciók magyar-szerb vizsgálatok tükrében. MTA Regionális Kutatások Központja, Alföldi Tudományos Intézet, Békéscsabai Osztály, Békéscsaba, 81-94.

Nagy T. (2008): Relatív egzotikum. In: Fejős Z., Pusztai B. (szerk.): Az egzotikum. Néprajzi Múzeum - SZTE Kommunikáció- és Médiatudományi Tanszék, Budapest-Szeged, 173-188., (Tabula Könyvek; 9.)

Nagy T. (2009): Narratív menekültsors. A hatalom és mobilitás kérdései. In: Jancsák Cs., Nagy G. D., Szücs N. (szerk.): Céhem vándorkönyvei. Tanulmányok a 60 éves Pászka Imre tiszteletére. Belvedere Meridionale, Szeged, 89-103.

Nagy T. (2010): A menekültek mobilitása néhány szempont szerint. A neointegráció és a mobilitás. In: Jancsák Cs., Nagy G. D., Pászka I. (szerk.): Állandó párbeszédben. A szegedi mühely tisztelgése Utasi Ágnesnek. Belvedere Meridionale - DARTKE, Szeged, 212-235.

Olomoofe, L. (2000): Egy fekete közösség létrejötte Budapesten? In: Sik E., Tóth J. (szerk.): Diskurzusok a vándorlásról. MTA PTI Nemzetközi Migráció Kutatócsoport, Budapest, 50-59. 
Phillimore, J. (2011): Refugees, Acculturation Strategies, Stress and Integration. Journal of Social Policy, 3., 575-593.

Safran, W. (1991): Diasporas in Modern Societies. Myths of Homeland and Return. Diaspora, 1., 83-99.

Sassen, S. (1999): Whose City Is It? Globalization and the Formation of New Claims. In: Holston, J. (ed.): Citites and citizenship. Duke University Press, Durham, 177-194.

Sik E., Tóth J. (szerk.) (1996): Táborlakók, diaszpórák, politikák. MTA PTI Nemzetközi Migráció Kutatócsoport, Budapest

Sik E., Tóth J. (szerk.) (1998): Idegenek Magyarországon. MTA PTI Nemzetközi Migráció Kutatócsoport évkönyve, MTA Politikai Tudományok Intézete, Budapest

Sik E., Tóth J. (szerk.) (2000): Diskurzusok a vándorlásról. Budapest: MTA PTI Nemzetközi Migráció Kutatócsoport, Budapest

Simmel, G. (2004): Exkurzus az idegenről. In: Biczó G. (szerk.): Az Idegen. Variációk Simmeltől Derridáig. Csokonai Kiadó, Debrecen, 56-60.

Tilly, Ch. (2001): Áthelyeződött hálózatok. In: Sik E. (szerk.): A migráció szociológiája. Szociális és Családügyi Minisztérium, Budapest, 89-103.

Wahlbeck, Ö. (2002): The concept of diaspora as an analytical tool in the study of refugee communities. Journal of Ethnic and Migration Studies, 2., 221-238.

Waldenfels, B. (2004): Az idegenség etnográfiai paradoxonjainak ábrázolása. In: Biczó G. (szerk.) Az Idegen. Variációk Simmeltól Derridáig. Csokonai Kiadó, Debrecen, 91-116.

Wiles, J. (2008): Sense of home in a transnational social space: New Zealanders in London. Global Networks, 1., 116-137.

Wilson, T. F. (2009): The conservative aspects of a centripetal diaspora: The case of the Cape Verdean tabancas Africa. The Journal of the International African Institute, 4., 520-542. 